\title{
Mekanların Benimsenmesi ve Olumlu Değerler Yüklenmesi: Bursa Orhangazi Meydanı
}

\author{
Elvan ENDER ALTAY*1 ${ }^{*}$ Zeynep EYÜPOĞLU², Ayşegül BOZKURT ${ }^{2}$ \\ ${ }^{1}$ Bursa Uludağ Üniversitesi, Ziraat Fakültesi, Peyzaj Mimarlığı Bölümü,16059, BURSA \\ ${ }^{2}$ Bursa Uludağ Üniversitesi, Fen Bilimleri Enstitüsü, Peyzaj Mimarlığı Anabilim Dalı,16059, BURSA
}

\section{Öz}

Kentsel açık alanlar kentlerin kimliğini oluşturan önemli bileşenlerdendir. Meydan biçiminde ortaya çıkan ilk kentsel açık mekânlar, kentlerin kültürünü yansıtmakta ve kentlerin özelliklerine göre farklı nitelikleri barındırmaktadır. Meydanların niteliklerini etkileyen kentsel tasarım ögeleri ile beraber o mekânı kullanan kullanıcıların o mekanda hissettikleri ile bütünleşmektedir. Mekânın niteliklerinin artırılması mekansal davranışsal performansı da artırabilecek ve aynı zamanda o mekanın benimsenerek mekana olumlu değerler yüklenmesine katkı sağlayabilecektir. Çalışma; Bursa kent merkezinde yoğun kullanıma sahip Orhangazi Meydanı'nın mekânsal performansını belirlemek amacıyla yapılmıştır. Mekânın davranışsal performansını belirlemek için 43 ölçüt belirlenmiştir. Ağırlıklandırılmış ölçütler yöntemiyle meydanın mekânsal performans puanı 393,70 (\% 85,43) hesaplanmıştır.

Anahtar Kelimeler: Ağırlıklandırılmış ölçütler yöntemi, Bursa, kentsel açık alanlar, meydan.

\section{Adopting Spaces and assigning positive values: Bursa Orhangazi Square}

\begin{abstract}
Urban open spaces are one of the important components that make up the identity of cities. The first urban open spaces that emerged in the form of squares reflect the culture of the cities and have different qualities according to the characteristics of the cities. Together with the urban design elements that affect the qualities of the squares, it integrates with the feelings of the users who use that space. Increasing the qualities of the space will also increase the spatial behavioral performance, and at the same time, it will contribute to the adoption of that space and to add positive values to the space. This research was made to determine the spatial performance of Orhangazi Square, which is heavily used in the city center of Bursa. 43 criteria were determined to determine spatial performance. The spatial performance score of the square was calculated as $393.70(85,43 \%)$ using the weighted criteria method.
\end{abstract}

Keywords: Weighted criteria method, Bursa, urban open spaces, square.

\footnotetext{
*Sorumlu Yazar (Corresponding Author):

Elvan ENDER ALTAY (Doç.Dr.); Bursa Uludağ Üniversitesi, Ziraat Fakültesi, Peyzaj

Mimarlığı Bölümü, 16059, Bursa-Türkiye. Tel: +90 (224) 294 1639. E-mail:

elvanender@uludag.edu.tr. ORCID: 0000-0001-5933-1611
} 


\section{Giriş}

\subsection{Meydan Kavramı}

Kent, kullanıcılarının ortak paylaşımının mekânsal bir şekilde oluşturulduğu bir alan olarak karşımıza çıkmaktadır. Diğer bir deyişle kent, toplumsal yapının oluştuğu fiziksel alandır. Her kentin düzenli bir şekilde ortak yaşamının geçtiği kentsel mekânlar vardır. Bu mekânlar, kentte önemli etkilere sahiptir. Kentsel mekanlar bu bağlamda, geçmişteki olayların izlerinin bulunduğu ve farklı deneyimlerin farklı şekillerle ifade edildiği yerlerdir (Ringas vd,. 2011). Meydan biçiminde ortaya çıan ilk kentsel mekânlar, kentin kültürünü yansıtmaktadır. Bu mekânlar geçmişle gelecek arasında bağlantı kuran kültürel ortamlardır. Bu tanıma uygun olarak meydanlar, toplumsal yaşamı sürdürebilmek için gerekli olan bir araya gelme gereksiniminden doğmuş, kent kimliğinin oluşumunda önemli bir öge olarak ortaya çımıştır (Uzgören ve Erdönmez, 2017).

"Meydanlar" geniş ve düz alan olarak tanımlanmakla beraber, kentsel sirkülasyonu başlatma ve yönlendirme ile kent insanına toplanma mekânı olarak hizmet veren geniş açık alanlar olup bu mekânlar, kentlerin odak noktalarıdır (Zucker, 1959; Küçükerbaş ve Özkan, 1994; Oktay, 2007). Aynı zamanda, kent yaşamının önemli bir parçası olan kamusal mekânlardır. Meydanlar, her kentin doğal, kültürel, sosyal ve ekonomik özelliklerine göre farklı içerik ve fonksiyonlara sahiptir (Uzgören ve Erdönmez, 2017). Meydanların, gelişen ve değişen sosyal ve kültürel yapının şekillenmesinde önemli bir payı vardır. Meydanların biçimleri ya da işlevleri ile nitelendirilmelerinin yanında kullanıcılarında bir "yer" e ait olma duygusu yaratmaları da o meydanın niteliğini göstermektedir. Zucker (1959)'a göre meydan kent dokusu içinde adeta "psikolojik bir dinlenme yeri"dir. Meydanın tarih içindeki gelişimi incelendiğinde, en başarılı meydanların kent yaşamının doğal bir parçası olan mekânlar olduğu ve fiziksel olarak çok iyi tanımlanmış oldukları görülmektedir (Relph, 1976).

Meydanlar kentsel yapının en belirgin bileşeni olup, binaların mekân etrafında oluşturdukları süreklilik ile biçimlenirler. Meydanı, yani kentsel boşluğu yaratan şey onları çevreleyen yapılardır. Yapıların dokularına ve işlevlerine göre meydanın anlamı farklılaşmaktadır. Böylece mimari mekanın meydana akan boşluklarıyla meydan bir olmaktadır. Bir tür kentsel boşluk olan meydanlar kendilerini sınırlayan mimari öğelerle boşluklar vasıtasıyla ilişki kurmaktadır. Bu durum da en yoğun tarihi meydanlarda görülmektedir. Tarihi meydanlar yerlerini meydanı çevreleyen tarihi yapılar ya da tarihi öğelerin boşluklarının oluşturduğu kentsel alanlara birakmaktadır (Kuloğlu, 2013).

\subsection{Tarihi Meydanlar}

Meydan kent ölçeğinde dini yapılar, surlar, hanlar, camiler vb. mekanların, mahalle ölçeğinde ise cami, çeşme, anıtsal ağaç vb. mekanların etrafında oluşmaktadır. Meydanlar sosyo-kültürel yaşamla ilişkili mekanlarda geçmekte ve meydanlar bu çerçevede gelişmektedir. Meydanlar bu çerçeve etrafında değerlendirildiğinde tarihi özelliği meydanlara katan içerisinde bulunduğu çevre ve barındırdığı yapılardır.

Tarihi meydanlar tarihi yapıların çevrelediği kentsel açık alanlardır. Kent kültürü ve tarihin özellikleri tarihi meydanlara yansımaktadır. Meydanın etrafında bulunan hanlar, camiler, surlar, çarşılar gibi tarihi binalar meydana kimlik özelliğini ve tarih dokusunu katan yapılar olup meydanın oluşumunu ve gelişimini etkilemektedir (Ateş, 2020).

\subsection{Meydan Kullanımı ve Tasarımı}

Kentsel tasarımla ilgili araştırmalara göre "kullanım" etmeni mekânın niteliğinin en önemli belirleyicisidir. Bir meydanın kullanımını belirleyen temel koşul, kolay erişilebilir olması ile farkı kesimler ve yaş gruplarından kullanıcıları çekebilecek işlevsel çeşitliliği içermesidir (Whyte, 1980/1988; Cooper Marcus, 1990; Madanipour 1996/2003; Carmona ve diğerleri 2003; Lang 2005).

Meydanın kullanıcılarında bir yer ve aidiyet duygusu oluşturma durumu meydanların kullanımını ve yoğunluğunu arttırmaktadır, Bir "yer"e ait olma duygusu insanların çok önemli bir gereksinimi olup, bu duygunun gerçekleşmesi, o yerin kendine özgü ve oradaki insanları saran coğrafi, tarihsel, toplumsal ve özellikle estetik özelliklerinin oluşturduğu alan karakterine bağlıdır (URL 1) Mekânsal anlamda "yer duygusunun" en saf şekilde ifade edilişi çevrili olma hissi ve kuşatılmışlıkla ilişkilendirilmektedir. Doğal-yapay öğelerle çevrili meydanların benimsendiği ve bu meydanlara olumlu değerlerin yüklendiği görülmektedir (Alexander vd.,1977; Krier, 1979)

Meydanın kullanımını artırabilecek tasarım ögelerinin uyumlu olması açısından alana ait örüntülerin iyi bilinmesi gerekmektedir. İnsan-mekân ilişkisini kuvvetlendirmek için, gün içinde kullanım çeşitliliğini artıracak 
aktivitelerin meydan yaşamına dâhil edilmelidir. İnsan ve meydanı kuşatan doğal-yapay öğeler arasındaki algılama ölçeğinin, insan mekân psikolojisi bağlamında değerlendirilmeli ve meydanın kimliğinin tüm kullanıcılar için farklı anlam yüklenebilen bir yer haline gelmesi sağlanmalıdır.

Meydanların niteliklerini etkileyen kentsel tasarım öğeleri, meydanın çevresiyle meydanı birleştirmelidir. Her bir öğenin meydanın niteliğini arttırmada etkisi bulunmaktadır. Meydanda bulunan ya da mekânı sınırlayan yapıların veya diğer ögelerin, ölçü, malzeme, renk ve ışık etkisi de meydana farklı boyutlar kazandırmaktadır (Giritlioğlu, 1991). Mekânın niteliklerinin artırılması mekanın davranışsal başarımını (performansını) da artırabilecek ve aynı zamanda o mekanın benimsenerek olumlu değerler yüklenmesine katkıda bulunabilecektir (Glazer ve Lilla, 1987; Konaklı vd., 2010; Altay ve Batman, 2019).

Meydana ait kültürel, toplumsal ve tarihi belleğe ait izlerin, sürekliliğinin sağlanması alanın sürdürülebilirliği açısından gerekmektedir. Tarihi çevre özelliklerinin, sadece mevcut veriler ile sınırlı kalmayıp, meydan tasarımına tarihi yaşatacak bir bakış açısıyla yön verilmelidir. Meydana özel gelişme dinamiklerinin belirlenmesi ve bu dinamiklere göre tasarımın yönlendirilmesi önemlidir.

Meydan tasarımlarında biçimsel çeşitlilik yoluyla mekâna boyut kazandırılabilmektedir. Bu bağlamda temel meydan tasarımında temel ilke "çeşitlilik içinde birlik" olarak yapay öğelerin üslup ve oranlarının, renk ve malzemelerinin, binalar, mekânlar ve doğal peyzaj arasındaki ilişkilerin en olumlu etkiyi yaratması hedeflenmelidir. Meydanlarda, geçmişle bağların kurulması kimlik ve yer duygusunun artırılmasında ve toplumsal belleğin güçlendirilmesinde esastır. Bu nedenle, meydanların tarihî çevrenin bir parçası olduğu yerlerde, sosyo-ekonomik ve kültürel yapıya uyumlu koruma ve canlandırma ile sürdürebilirlik özel bir önem kazanmaktadır.

Meydan içinde sanatsal öğeler de anlamı, kimliği ve yönelimi güçlendirebilir. Bu elemanlar, bulundukları mekânın imgesini ve okunabilirliğini güçlendirirken, meydana farklı anlamların da yüklenmesine destek olabilirler. Sanatsal öğeler ile bulunduğu meydandaki doku arasında uyumlu bir ilişki ve bütünleşmenin sağlanması ve öğelerin yaya hareketinin yoğunluğu dikkate alınarak konumlandırılması önemlidir (URL 1).

Bu araştırmada; meydanların tasarımında dikkat edilmesi gereken ölçütler belirlenmiş, Bursa kent merkezinde yoğun kullanıma sahip tarihi yapılarla çevrili Orhangazi Meydanı’nın mekânın davranışsal performansının belirlenmesi amaçlanmıştır.

\section{Materyal ve Metot}

\subsection{Materyal}

Çalışmanın ana materyalini Bursa kentinde bulunan Orhangazi Meydanı oluşturmaktadır. Çalışma alanının konumu Şekil 1'de, fotoğrafları Şekil 2'de verilmiştir. 

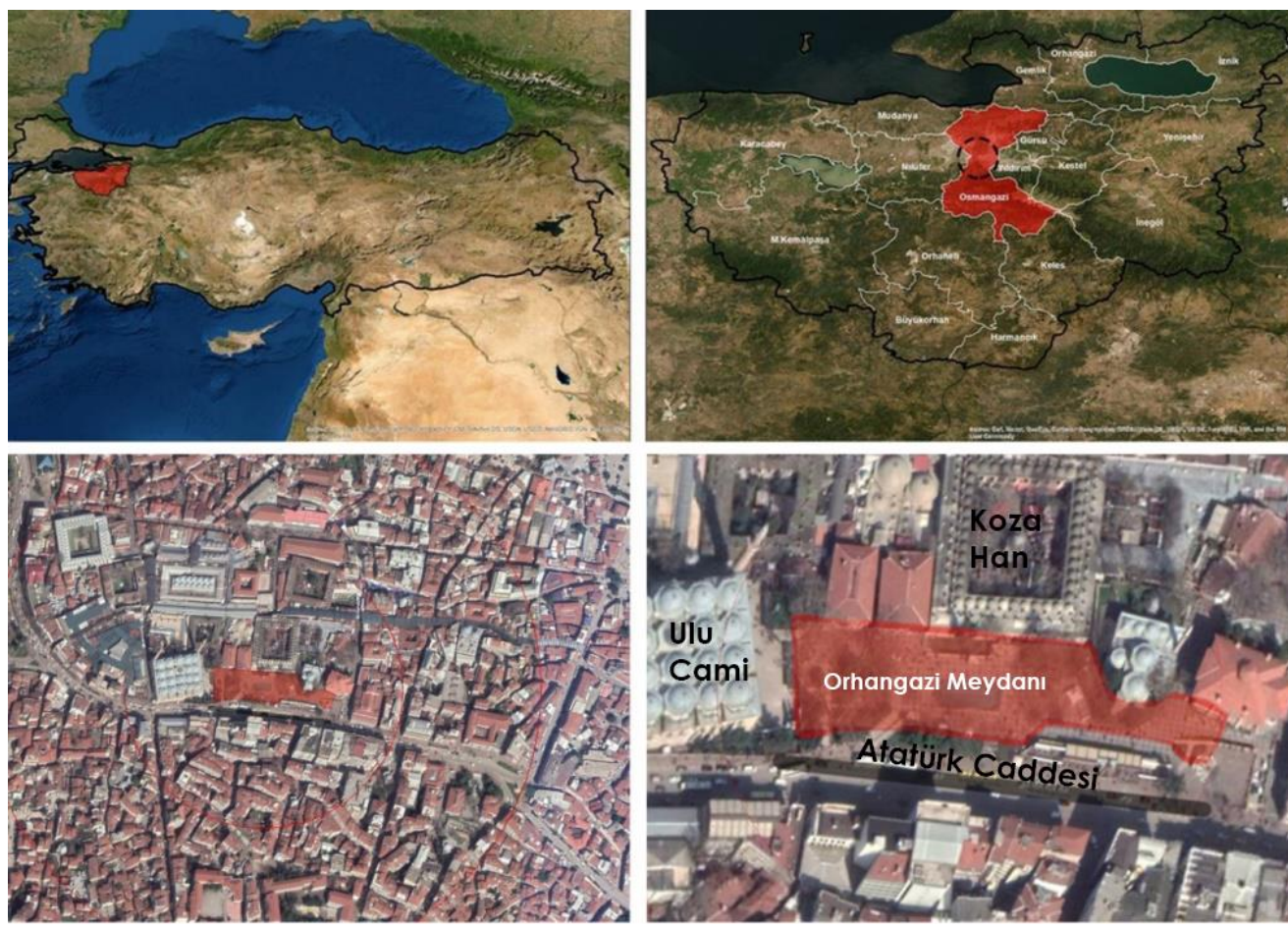

Şekil 1. Çalışma Alanının Konumu

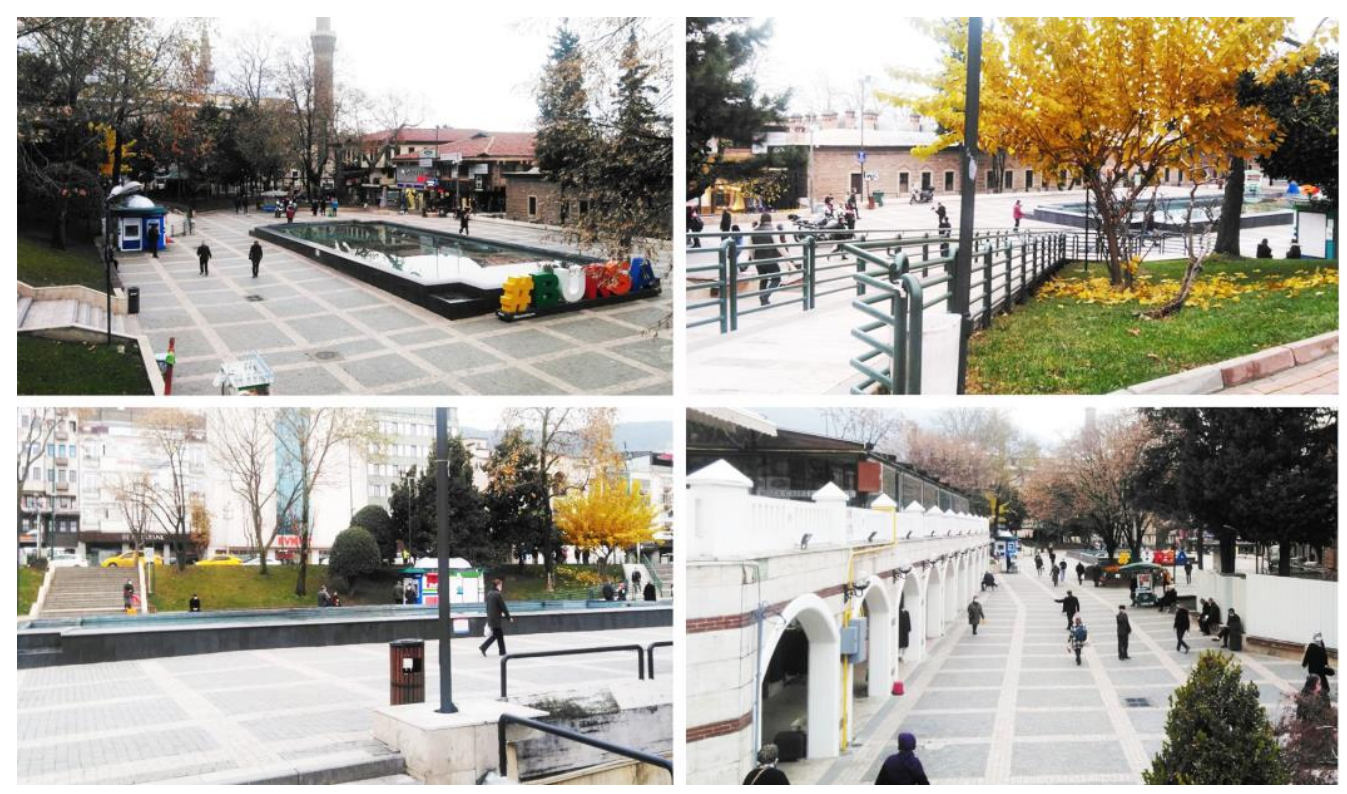

Şekil 2. Çalışma Alanının Fotoğrafları (Orijinal)

Orhangazi Meydanı, Bursa kent merkezinde yer alan Hanlar Bölgesinde bulunmaktadır. Mimari tasarımı 1983 yılında Şaziment-Neşet Arolat tarafından yapılmıştır ve 1986'da kullanıma açılmıştır. Meydanın yakın çevresinde Ulucami, Kapalıçarşı, Koza Han, Orhan Camii, Büyükşehir Belediyesi Başkanlık Binası, sanat galerisi ve Orhangazi altgeçit çarşısı bulunmaktadır (URL 2). Meydanın çevresindeki diğer alan kullanımları Şekil 3'te verilmiştir. 


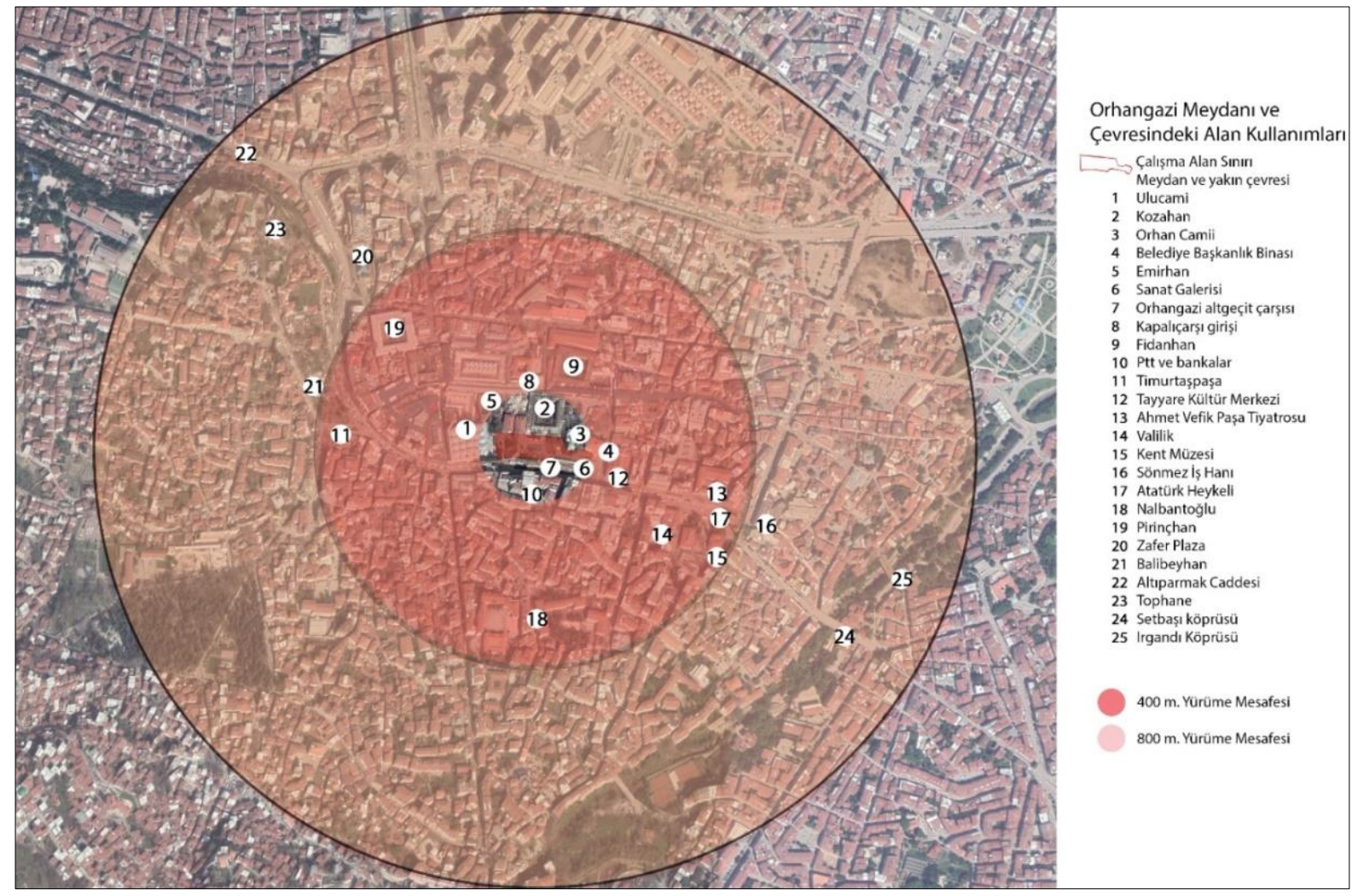

Şekil 3. Araştırma Alanı ve Çevresindeki Alan Kullanımları

Önemli tarihî binalar ile çevrili olan Orhangazi Meydanı Atatürk Caddesi sınırında bulunmaktadır. Meydan $5200 \mathrm{~m}^{2}$ alana konumlanmıştır.

\subsection{Metot}

Çalışma Yöntemi,

- Çalışmada temel alınacak mekan ölçütlerinin belirlenmesi,

- Belirlenen ölçütlerin puanlarının ve katsayılarının hesaplanması

• “Ağırlıklandırılmış Ölçütler Yöntemi” nin uygulanması olarak üç aşamadan oluşmaktadır.

Ölçütlerin Belirlenmesi: Yöntemin ilk aşamasında meydanları değerlendirme ölçütleri ve bu ölçütler kapsamında değerlendirmede kullanılacak nitelikler belirlenmiştir. Bu amaçla açık alanlar konusunda yurtiçi ve yurtdışında yapılmış araştırmalardan belirlenen ölçütler ve bu ölçütlerin kapsamları irdelenmiştir.

Belirlenen Ölçütlerin Puanlarının ve Katsayılarının Hesaplanmast: Tablo 1'de verilen toplam 43 adet değerlendirme ölçütünün toplamının 100'ü oluşturacak şekilde her bir ölçüt için yüzdelik puanlar atanarak çalışmanın amacına uygun bir değerlendirme dizgesi oluşturulmuştur. 43 ölçütün her biri \%2,32 etki oranına sahiptir. Bu ölçütlerin puanlanması kapsamında ölçütü tanımlayan niteliklerin meydanda bulunma durumu önemlidir. 43 ölçüt alanda bulunan kullanıcılar tarafından değerlendirilmiş ve ölçütler alanda bulunma durumuna göre puanlanarak ölçüt puanları oluşturulmuştur. Kullanıcılara yapılan anket sonucunda, ölçüt niteliğinin meydanda bulunma durumu belirlenmiş̧tir. Anket yapılacak örneklem büyüklüğü ana kütle büyüklüğü bilinmediği için aşağıdaki formülle hesaplanmıştır (Vural, 2012).

Örneklem $n=t^{2} \mathrm{pq} / \mathrm{d}^{2}$

n: Örneklem büyüklüğü

p: İlgilenilen olayın görülme olasıllı̆ı $(0,10)$

q: $1-p$ (veya ilgilenilen olayın görülmeme olasıllığ $)(0,90)$

$\mathrm{d}$ : kabul edilen \pm örnekleme hata oranı $(0,05)$

$\mathrm{t} \_(\alpha, \mathrm{sd}): \alpha$ anlaml1l1k düzeyinde, serbestlik derecesine göre $\mathrm{t}$ tablosu kritik değeri $(1,96)$

Örneklem büyüklüğ̈̈ 138'dir. 
Çalışmada kullanılan ölçütlerin ölçüt katsayılarını belirlemek için 30 uzmana standart formlarda anket çalışması uygulanmıştır. Ölçüt katsayıları, 1; en düşük ölçüt puanı, 5; en yüksek ölçüt puanı olarak 1-5 arasında puanlanmıştır. Puanlanan ölçütlerin aritmetik ortalamaları hesaplanarak ölçüt katsayıları ayrı ayrı verilmiştir.

“Ăğırlıklandırılmış Ölçütler Yöntemi” nin uygulanması: Orhangazi Meydanı'nın değerlendirilmesi için belirlenen ölçütlere değer atama ve hesaplamalarda; ilk olarak Gold (1980) tarafindan Santa Barbara kenti (ABD) örneğinde açıklanan, Altunkasa ve Yücel (1998), Altunkasa vd. (1999), Uslu vd. (2004), Gültekin (2007) ve Demirel (2008), Ender (2011), Kalkan (2013), Ünal (2014), Ender ve Uslu (2018) ve Altay ve Batman (2019) tarafından bisiklet yolu, meydan, yaya yolu ve aktif yeşil alanlar gibi mekanlarda uygulanan ve çalışmaları başarılı sonuçlara ulaştıran “A Ăırlıklandırılmış Ölçütler Yöntemi” temel alınmıştır.

Ölçüt için verilen puan ile ölçütün katsayısının çarpımı ölçütün ağırlıklı puanını göstermektedir. Bu işlemi aşağıda verilen formülle özetlemek mümkündür.

\section{Ăğırlıklandırılmış Ölçüt Puanı = K1 (1. Ölçütün katsayısı) $x$ ÖP1 (1. Ölçütün Puanı)}

Elde edilen ağırlıklı puanların toplanması ile mekanın toplam puanına ulaşılmıştır. Toplam puan 100 e göre endekslenerek, mekanın davranışsal performansı (olumlu değerlerin hesaplanması) yüzde olarak ortaya konmuştur. Yöntemle elde edilen puanlar ve bulgular doğrultusunda Orhangazi Meydanı için iyileştirme yaklaşımları ve öneriler geliştirilmiştir.

\section{Bulgular}

\subsection{Değerlendirme ölçütleri}

Meydanların değerlendirme ölçütleri ve bu ölçütler kapsamında değerlendirmede kullanılacak nitelikler Arnheim (1977), Trancik (1986), Lang (1987), Baker (1989), Aalborg(1994), Nasar (1994), Özer ve Ayten (1995), Aklanoğlu ve Arslan (2002), Hacıhasanoğlu ve Aytem (2005), Günal (2006), Oktay (2007), İnceoğlu ve Aytuğ (2009), Çınar(2009), Çanaçıŏlu (2011), Eren (2012), Taşçı (2012), Çınar vd. (2014), Semerci (2014), Şahin (2015), Erdönmez ve Çelik (2016), Aytaş (2017), Uzgören ve Erdönmez (2017), Durak (2018), Acarl1 ve Kiper (2018), Argan (2019), Altay ve Batman (2019), Hançer (2019), Karakaş (2019), Özer (2019), Torlak ve Yerli (2019), Tanrıbir ve Akten (2020), Tırnakçı (2020), Pouya ve Sekmen (2020), Gündoğdu ve Uğuz (2020), Demir vd. (2021)'in yaptıkları çalışmalardan geliştirilerek oluşturulmuştur. Çalışma kapsamında 43 mekan ölçütü belirlenmiş ve Tablo 1'de verilmiştir. Belirlenen ölçütler meydanda incelenerek puanlandırması yapılmıştır (Tablo 1).

Tablo 1. Araştırma Kapsamında Belirlenen Ölçütler ve Puanları

\begin{tabular}{|c|c|c|c|c|c|}
\hline No & Algı Ölçütü & Ölçüt Niteliği & Puan & Değerlendirme & $\begin{array}{c}\text { Toplam } \\
\text { Puan }\end{array}$ \\
\hline \multirow{3}{*}{1.} & \multirow{3}{*}{ Renk Kullanımı } & $\begin{array}{l}\text { Dinlendirici (Mekânda en fazla } 3 \\
\text { renk kullanımı) }\end{array}$ & 0,77 & + & \multirow{3}{*}{2,32} \\
\hline & & Uyum ve zıtlık dengesi & 0,77 & + & \\
\hline & & Samimi & 0,77 & + & \\
\hline \multirow{3}{*}{2.} & \multirow{3}{*}{ Biçim Kullanımı } & Büyük & 0,77 & + & \multirow{3}{*}{2,32} \\
\hline & & Düzenli & 0,77 & + & \\
\hline & & Yüzeylerin algılanması & 0,77 & + & \\
\hline \multirow{2}{*}{3.} & \multirow{2}{*}{ Doku Kullanımı } & Doğal doku(yumuşak doku) & 1,16 & + & \multirow{2}{*}{2,32} \\
\hline & & Yapay doku(sert doku) & 1,16 & + & \\
\hline \multirow{3}{*}{4.} & \multirow[t]{3}{*}{ Form Kullanımı } & $\begin{array}{l}\text { Etkili(alışılmışın dışında bir formla } \\
\text { karşılaşmak) }\end{array}$ & 0,77 & - & \multirow{3}{*}{1,55} \\
\hline & & Dinamik & 0,77 & + & \\
\hline & & Sinırlı & 0,77 & + & \\
\hline \multirow{4}{*}{5.} & \multirow{4}{*}{ Işık Kullanımı } & Parlaklık/matlık & 0,58 & + & \multirow{4}{*}{1,74} \\
\hline & & Yansima & 0,58 & + & \\
\hline & & $\begin{array}{l}\text { Etkili(alışılmışın dişında bir ışıkla } \\
\text { karşılaşmak) }\end{array}$ & 0,58 & - & \\
\hline & & Yeterli / güvenli & 0,58 & + & \\
\hline \multirow{3}{*}{6.} & \multirow{3}{*}{ Görsel Tatmin } & Canlı materyal(Bitki varlığı) & 0,77 & + & \multirow{3}{*}{1,55} \\
\hline & & $\begin{array}{l}\text { Cansız materyal(Sanatsal öge heykel } \\
\text { vb.) }\end{array}$ & 0,77 & - & \\
\hline & & $\begin{array}{l}\text { Uyum ve zitlik dengesi (form, } \\
\text { materyal ) }\end{array}$ & 0,77 & + & \\
\hline
\end{tabular}


Tablo 1. Devam ediyor.

\begin{tabular}{|c|c|c|c|c|c|}
\hline No & Algı Ölçütü & Ölçüt Niteliği & Puan & Değerlendirme & $\begin{array}{c}\text { Toplam } \\
\text { Puan }\end{array}$ \\
\hline \multirow{2}{*}{7.} & \multirow[t]{2}{*}{ İşitsel Tatmin } & $\begin{array}{l}\text { Rahatsız edici seslerin } \\
\text { olmaması(trafik, makine vb.) }\end{array}$ & 1,16 & - & \multirow{2}{*}{1,16} \\
\hline & & $\begin{array}{l}\text { Huzur veren seslerin olmasi ( Su sesi, } \\
\text { kuş sesi) }\end{array}$ & 1,16 & + & \\
\hline \multirow{3}{*}{8.} & \multirow{3}{*}{ Kokusal Tatmin } & Doğal koku Bitki (aromatik bitki & 1,16 & + & \multirow{3}{*}{2,32} \\
\hline & & kullanımı, çıçeklı bitkı) & & & \\
\hline & & egzoz vb.) & 1,16 & + & \\
\hline 9. & Dokunsal Tatmin & Mekânda farklı dokuların varlığ 1 & 2,32 & + & 2,32 \\
\hline \multirow{3}{*}{10.} & \multirow{3}{*}{ Tanımlanabilirlik } & Yönlendirme & 0,77 & + & \multirow{3}{*}{2,32} \\
\hline & & Konseptin anlaşı1ması & 0,77 & + & \\
\hline & & Mekân ayrımının hissedilmesi & 0,77 & + & \\
\hline \multirow{2}{*}{11.} & Okunakl111k/ & Proporsiyon & 1,16 & + & \multirow{2}{*}{2,32} \\
\hline & Açıklık & Düzenli olması & 1,16 & + & \\
\hline \multirow{2}{*}{12.} & \multirow{2}{*}{ Fonksiyonellik } & Temanın anlaşılması & 1,16 & + & \multirow{2}{*}{2,32} \\
\hline & & Mekân işlevlerinin uygunluğu & 1,16 & + & \\
\hline \multirow{2}{*}{13.} & Tasarımda & Canlı materyal çeşitliliği & 1,16 & + & \multirow{2}{*}{2,32} \\
\hline & Çeşitlilik & Cansız materyal çeşitliliği & 1,16 & + & \\
\hline \multirow{3}{*}{14.} & \multirow{3}{*}{ Sürdürülebilirlik } & Uygun Malzeme & 0,77 & + & \\
\hline & & Uygun bitki & 0,77 & + & 155 \\
\hline & & $\begin{array}{l}\text { Geri dönüşüm ya da yenilenebilir } \\
\text { enerii kaynaklarının kullanılması. }\end{array}$ & 0,77 & - & 1,50 \\
\hline & Denge İlkesine & Ölçekteki uygunluk & 0,77 & + & \\
\hline 15. & Uygunluk & Canlı materyalin homojen dağılımı & 0,77 & - & 1,55 \\
\hline & & Cansız materyalin homojen dağılımı & 0,77 & + & \\
\hline & Düzen İlkesine & Fonksiyonların birbiriyle uyumlu & 1,16 & & \\
\hline 16. & Uygunluk & olmas1 & ser & + & 2,32 \\
\hline & & Dengeli olma & 1,16 & + & \\
\hline & Bütünleşik Tasarım & $\begin{array}{l}\text { Canlı materyaller arasındaki } \\
\text { bütünlük }\end{array}$ & 1,16 & + & \\
\hline 17. & & $\begin{array}{l}\text { Cansız materyaller arasındaki } \\
\text { bütünlük }\end{array}$ & 1,16 & + & 2,32 \\
\hline 18. & $\begin{array}{l}\text { Mekân İçinde } \\
\text { Uyum }\end{array}$ & $\begin{array}{l}\text { Tasarım ögelerinin her birinin uyumu } \\
\text { (renk, biçim, doku ve form) }\end{array}$ & 2,32 & + & 2,32 \\
\hline 19. & Çevreyle İlişkili & $\begin{array}{l}\text { Mekân ve çevresindeki kimliğin } \\
\text { uyumu }\end{array}$ & 2,32 & + & 2,32 \\
\hline & & Yönlendirme & 0,77 & + & \\
\hline 20. & Yön Bulabilme & Düzenli olma & 0,77 & + & 2,32 \\
\hline & & Kolay hareket edebilme & 0,77 & + & \\
\hline 21. & $\begin{array}{l}\text { İnsan Ölçeğiyle } \\
\text { Uyumlu }\end{array}$ & Ölçekteki uygunluk & 2,32 & + & 2,32 \\
\hline & Endise ve & Samimi & 0,58 & + & \\
\hline 22. & Korkudan Uzak & Aydınlık & 0,58 & + & 232 \\
\hline 22. & & Ferah & 0,58 & + & 2,52 \\
\hline & & Güvenli & 0,58 & + & \\
\hline 23. & Devinduyum & Hareketlilik imkânı & 2,32 & + & 2,32 \\
\hline & Bireysel Gelişime & Sosyal gelişim imkânı & 0,77 & + & \\
\hline 24. & Açık & Bilișsel gelișim imkânı & 0,77 & - & 1,55 \\
\hline & & Motor gelişim imkânı & 0,77 & + & \\
\hline 25. & Düşünmeye imkân & Konforlu & 1,16 & + & 1.16 \\
\hline 20. & veren & Sakin & 1,16 & - & 1,10 \\
\hline 26 & Sniritïel Baŏlant & Sakin & 1,16 & - & 116 \\
\hline 26. & Spirituel Baglant1 & Aidiyet hissi & 1,16 & + & 1,10 \\
\hline 27. & Yumusak Mekân & Su yüzeylerinin varlığı & 1,16 & + & 232 \\
\hline $2 \%$ & Yumuşak Miekan & Bitkilerin varlığ 1 & 1,16 & + & 2,32 \\
\hline 28 & Aidiyet Hissi & Samimi & 1,16 & + & 232 \\
\hline 28. & & Güvenli & 1,16 & + & 2,32 \\
\hline & Samimi & Neşeli & 1,16 & + & \\
\hline 29. & & Aidiyet hissi & 1,16 & + & 2,32 \\
\hline & Güven Yaratan & Ferah & 0,77 & + & \\
\hline 30. & Guven Yaratan & Aydınlık & 0,77 & + & 2,32 \\
\hline & & Sinirli & 0,77 & + & \\
\hline 31. & Aydınlık & Sicak & 1,16 & + & \\
\hline 31. & & Ferah & 1,16 & + & 2,32 \\
\hline
\end{tabular}


Tablo 1. Devam ediyor.

\begin{tabular}{|c|c|c|c|c|c|}
\hline No & Algı Ölçütü & Ölçüt Niteliği & Puan & Değerlendirme & $\begin{array}{c}\text { Toplam } \\
\text { Puan }\end{array}$ \\
\hline \multirow{2}{*}{32.} & \multirow[t]{2}{*}{ Özgürlük Hissi } & Sinırları olmayan & 1,16 & - & \multirow{2}{*}{1,16} \\
\hline & & Ferah & 1,16 & + & \\
\hline \multirow{3}{*}{33.} & \multirow{3}{*}{ Rahatlık Hissi } & Dinlendirici & 0,77 & + & \multirow{3}{*}{1,55} \\
\hline & & Konforlu & 0,77 & + & \\
\hline & & Sakin & 0,77 & - & \\
\hline \multirow{3}{*}{34.} & \multirow{3}{*}{ Sıra dışı } & Etkili & 0,77 & + & \multirow{3}{*}{1,55} \\
\hline & & Özgün & 0,77 & + & \\
\hline & & İlgi çekici & 0,77 & - & \\
\hline \multirow{3}{*}{35.} & \multirow{3}{*}{ İlgi Çekici } & Özgün & 0,77 & + & \multirow{3}{*}{1,55} \\
\hline & & Etkili & 0,77 & + & \\
\hline & & Sıra dişı & 0,77 & - & \\
\hline \multirow{2}{*}{36.} & \multirow[t]{2}{*}{ Canlandırıcı } & Canlı renklerin kullanımı & 1,16 & - & \multirow{2}{*}{1,16} \\
\hline & & Hareketlilik imkânı & 1,16 & + & \\
\hline \multirow{3}{*}{37.} & \multirow{3}{*}{ Devingen } & Değişken & 0,77 & + & \multirow{3}{*}{2,32} \\
\hline & & Hayvan & 0,77 & + & \\
\hline & & Canlı mekân & 0,77 & + & \\
\hline \multirow{3}{*}{38.} & \multirow{3}{*}{ Huzur Verici } & Ferah & 0,77 & + & \multirow{3}{*}{2,32} \\
\hline & & Aidiyet hissi & 0,77 & + & \\
\hline & & Aydınlık & 0,77 & + & \\
\hline \multirow{2}{*}{39.} & \multirow[t]{2}{*}{ Konforlu } & Uygun ergonomi & 1,16 & + & \multirow{2}{*}{2,32} \\
\hline & & Dinlendirici & 1,16 & + & \\
\hline \multirow{2}{*}{40.} & \multirow[t]{2}{*}{ Renkli } & Canlı ... & 1,16 & - & \multirow{2}{*}{0} \\
\hline & & İlgi çekici & 1,16 & - & \\
\hline 41. & Modern & Günümüze Uygunluk & 2,32 & + & 2,32 \\
\hline 42. & Estetik & $\begin{array}{l}\text { Tasarım ögelerinin etkili olması } \\
\text { (renk, biçim, doku ve form) }\end{array}$ & 2,32 & + & 2,32 \\
\hline \multirow{2}{*}{43.} & \multirow{2}{*}{ Bakımlı } & Temiz & 1,16 & + & \multirow{2}{*}{2,32} \\
\hline & & Sağlam & 1,16 & + & \\
\hline
\end{tabular}

Tablo 1’e göre 27 ölçütün tüm puanı karşıladığı görülmektedir.

\section{2. Ölçüt Katsayıları}

Uzmanların ölçütlerin her birine verdiği puanların ortalamalarıyla oluşturulan ölçüt katsayıları Tablo 2'de verilmiştir. Katsayılar 3,54 ile 5,00 arasında farklılık göstermektedir.

Tablo 2. Ölçüt Katsayıları.

\begin{tabular}{cccccc}
\hline No & Algı Ölçütü & Ort. & No & Algı Ölçütü & Ort \\
\hline 1 & Renk Kullanımı & 4,31 & 23 & Devinduyum & 4,60 \\
2 & Biçim Kullanımı & 4,63 & 24 & Bireysel Gelişime Açık & 3,76 \\
3 & Doku Kullanımı & 4,92 & 25 & Düşünmeye imkân veren & 4,81 \\
4 & Form Kullanımı & 4,57 & 26 & Spiritüel Bağlantı & 4,54 \\
5 & Işık Kullanımı & 5 & 27 & Yumuşak Mekân & 5 \\
6 & Görsel Tatmin & 5 & 28 & Aidiyet Hissi & 5 \\
7 & İşitsel Tatmin & 4,54 & 29 & Samimi & 4,55 \\
8 & Kokusal Tatmin & 4,12 & 30 & Güven Yaratan & 4,92 \\
9 & Dokunsal Tatmin & 4,62 & 31 & Aydınlık & 4,58 \\
10 & Tanımlanabilirlik & 5 & 32 & Özgürlük Hissi & 4,53 \\
11 & Okunaklılık/Açılık & 4,53 & 33 & Rahatlik Hissi & 4,56 \\
12 & Fonksiyonellik & 4,60 & 34 & Sıra dışı & 4,48 \\
13 & Tasarımda Çeşitlilik & 3,84 & 35 & İlgi Çekici & 4,55 \\
14 & Sürdürülebilirlik & 5 & 36 & Canlandırıcı & 3,62 \\
15 & Denge İlkesine Uygunluk & 4,63 & 37 & Devingen & 4,65 \\
16 & Düzen İlkesine Uygunluk & 4,92 & 38 & Huzur Verici & 4,56 \\
17 & Bütünleşik Tasarım & 4,63 & 39 & Konforlu & 5 \\
18 & Mekân İçinde Uyum & 4,81 & 40 & Renkli & 4,53 \\
19 & Çevreyle İlişkili & 4,60 & 41 & Modern & 3,54 \\
20 & Yön Bulabilme & 5 & 42 & Estetik & 5 \\
21 & İnsan Ölçeğiyle Uyumlu & 4,58 & 43 & Bakımlı & 5 \\
22 & Endişe ve Korkudan Uzak & 5 & & &
\end{tabular}




\subsection{Ağırlıklı puan}

Araştırma Kapsamında ölçütlerin alabileceği en yüksek puan 460,82'dir. Ağırlıklandırılmış ölçütler yöntemiyle hesaplanan ve her bir ölçütün ağırlıklı puanlarının (ölçütün katsayısı x ölçütün puanı) toplamı ise 393,70 olarak hesaplanmıştır.

\section{Sonuç ve Öneriler}

Çalışma alanında Lynch (1973), Arnheim (1977), Baker, 1989, Nasar (1994), Lang (1987), Trancik (1986), Aalborg (1994), Hacıhasanoğlu ve Aytem (2005), Özer ve Ayten (2005), Günal (2006), Çınar (2009), Çınar vd.(2014), Erdönmez ve Çelik (2016), Acarlı ve Kiper (2018), Argan (2019), Karakaş (2019), Torlak ve Yerli, Ö. (2019) Tanrıbir ve Akten (2020), Tırnakçı (2020), Pouya ve Sekman (2020), Gündoğdu ve Uğuz (2020), Demir vd. (2021), Taşçı (2012)'nin yaptığı çalışmalarda belirlenen ölçütlere ek olarak, Baker (1989), Aklanoğlu ve Arslan (2002) Oktay (2007), İnceoğlu ve Aytuğ (2009), Çanaçığlu (2011), Eren (2012), Semerci (2014), Şahin (2015), Aytaş (2017), Uzgören ve Erdönmez (2017), Durak (2018), Hançer (2019), Demir vd. (2021)'in yaptıkları çalışmalardan geliştirilerek 43 ölçüt değerlendirilmiştir.

Sonuç olarak; Orhangazi Meydanı 393,70 puan alarak mekanın davranışsal performansının \%85,43 ünü karşılamaktadır. Orhangazi Meydanı'ndaki hesaplamalar sonucunda eksiklikler belirlenmiş, eksikliklerin giderilmesi konusunda öneriler geliştirilmiştir.

- Fonksiyonellik ve estetik gibi ölçütleri dikkate alarak insanlara farklı gelebilecek formlar Orhangazi Meydanına özgünlük kazandırabilecektir. Bu tasarım bitki, havuz, dinlenme alanı, ışıklandırma gibi pek çok farklı alanda kullanılabilecektir.

- Orhangazi Meydanı'nda bulunan yapılar kültürü ve geçmişi yansıtır. Bu yapılar gün 1şı̆̆ında rahatlıkla görünürken geceleri ise iyi aydınlatma yapılmadığı için dikkat çekmemektedir. Işığın kalitesi, miktarı, yönü; şekil, renk ve formların rahat algılanabilmesi için önemlidir. Meydandaki Işığın etkisi; mevsimlere, gökyüzündeki bulut miktarına, gün içindeki zamana, başka obje tarafından oluşturulan gölge etkisine bağlıdır ve yaz mevsiminde farklı, kış mevsiminde farklı etki oluşturmaktadır (Özer, 2019). Orhangazi Meydanı'nda aydınlatmalarda yapılacak olan etkili aydınlatma görsel etkinin artırılmasına ve alandaki bu eksikliğin giderilmesine yardımcı olabilecektir.

- Görsel tasarımın duygusal ve zihinsel etkileri, mekanların benimsenmesinde rol oynamaktadır. Bir mekân tasarımında, işlevselliğin yanında kullanıcıların görsel memnuniyetinin olması, psikolojik ve fizyolojik gereksinimlerin karşılanmasında da etkili olabilecektir (Aytem, 2005). Orhangazi Meydanı'nda cansız materyal (sanatsal öge, heykel) olmadığı tespit edilmiştir. Bu ölçüt için meydanın konumuna ve çevresinde bulunan tarihi yapılara uygun materyaller tasarlanabilir.

- Meydana bağlantısı olan Atatürk Caddesi yoğun bir trafik akışına sahiptir. Bu trafik akışından gelen gürültü mevcut tramvay otobüs ve dolmuş durakları yanlarında bitkilendirme ile kısmen azaltılabilecektir.

- Günden güne önem kazanan sürdürülebilirlik kavramı meydanlarda sağlanabilmektedir. Bu da alanda gürültü ve çevre kirliliğinin önlenmesi, sürdürülebilir arazi kullanımı, biyoçeşitliliğin devamı, kamusal alana kolay erişim ve kentsel hareketlilik, aidiyet ve güvenlik gibi ölçütlerin sağlanması ile mümkün olabilecektir. Tüm atıkların geri dönüşümü için çözümler, yenilenebilir enerji üretim ve kullanımı, verimli ulaşım sistemlerinin geliştirilmesi, ekolojik (çevresel ve kültürel) farkındalığın geliştirilmesi, iyileştirmesine yardımcı olabilecektir.

- Mekânsal kompozisyonda, bileşenler bazı ilkeler 1şı̆̆ında bir araya getirilmekte ve bir düzen yaratılmaktadır. Ancak bir kompozisyonda düzenli, kurgulu öğelerin yanında, düzensiz rastlantısal düzenlemeler de etkili mekân oluşumuna katkı sağlayabilecektir. İnsanı etkileyen uyarıcı, basit ve özgün olan ya da düzen ve düzensizlik arasında doğru bir denge kurulduğu zaman estetik bir değer taşıyabilmektedir. Bir tasarımda önemli olan, birlik ile çeşitliliğin ya da karmaşıklığın dengeli birlikteliği sayesinde uyumun elde edilmesidir (Aytem, 2005). Bölgede bulunan yeşil alanların homojen dağılmaması alandaki sert zeminlerin fazla algılanmasına sebep olmaktadır. Meydanda bitki toplulukları mevcuttur ancak alan ile doğrudan bağlantısı bulunmamaktadır. Bitki topluluklarının çoğaltılması 
meydana ve tarihi yapılara (Ulucami, Koza Han, Orhan Camii) yönlendirme ve alanla bağlantı sağlayabilecektir.

- Orhangazi meydanında oluşturulacak yarı kapalı mekanlar veya örtülü bitki toplulukları ile sakin mekanlar yaratılabilir. İnsanın psikojik açıdan ferah olmasını ve spiritüel açıdan tatminini sağlayacak mekânlar bu meydandaki hareketlilik ve Atatürk Caddesine yakınlık dikkate alınarak insanın ihtiyaç duyduğu dinginliği yaşamasına olanak verebilecektir. Meydanın etrafı tarihi yapılar ile çevrilidir ve sınırlı bir alandır. Sakinlik ile birlikte özgürlük hissi de meydanda geliştirilecek bitkisel tasarım ile sağlanabilecektir.

- Orhangazi Meydanında ölçütün sağlanabilmesi için alanda bitkilendirme ve donatı tasarımları ile kişi veya topluluklara özel alanlar yaratılabilir. Mekândaki insan yoğunluğu ve alana bağlantılı trafik yoğunluğu dikkate alınarak bu tasarımlar yapılmalıdır.

- Orhangazi Meydanı, kentin imajını ve estetik yönünü vurgulamalı, aidiyet ve paylaşıma olanak sağlamalıdır. Bursa'da nirengi noktası olması sebebiyle de önemli rolleri bulunmaktadır. Bu meydanda, toplumsal bellek ve kent kimliği ile kurulacak etkileşimin kuvvetliliği, alanın ve kentin sahiplenilmesi ve korunması bakımından önem kazanmaktadır. Bu anlamda, toplumsal eylemlerin kentte yansıma bulduğu mekan olarak Orhangazi Meydanı'nda, sıra dışı (ilgi çekici) tasarımların sağlanması alana günümüzde yansıyan kendi dinamiğini gelecek nesillere aktarmada önemini vurgulamış olacaktır.

- Mekânda sıcak renk kullanımı mekânı daha yakın göstermesi ve insana enerji vermesi, insanın içini 1sıtması açısından katkı sağlamaktadır. Orhangazi Meydanında ise soğuk renkler hakimdir. Soğuk renkler mekânı daha uzak, huzur verici ve daha sakin algılanabilmesi açısından artı bir özellik kazandırmıştır. Sıcak renklerin de kullanımıyla enerji ve canlılık sağlanabilecektir.

- Kentsel açık alanlarda renkler kullanılırken ışı̆̆ın açısı ve yönü, işlev ve kimlik, kültürel yapı, iklim, malzeme seçimi, perspektifler ve kalite dikkat edilmesi gereken unsurlardır. Renk görsel açıdan algılanarak estetik amaçlara hizmet eder ve mekana derinlik, boyut katar. Renkler kullanım alanlarına göre mekânda algılanabilirlik, vurgu, yönlendirme, alana çeşitlilik kazandırma ve derinlik etkisi oluşturma gibi işlevlere sahiptir. Ayrıca renkler mekânda birlik, uyum ve kullanıcılar üzerinde olumlu psikolojik etkiler oluşturur (Özer, 2019). Bu sebeple meydandaki işlevlere uygun renklerle mekanın benimsenmesi güçlenebilecektir.

Çevre ve davranış kuramı, insanların çevreleri ile nasıl bir etkileşim içinde olduğuna yönelik soruları cevaplamaya yönelik bir araştırma alanıdır ve algı, bilişim, zihinsel şema ve davranış kavramlarını kapsamaktadır. Rapoport'a göre ise, insan ve çevre etkileşimlerindeki kavramlar, bir şeyin bilinmesi, hissedilmesi ve yapılması konularını kapsar. Bilişsel süreçler, algılama, bilme ve düşünmeyi, duyusal süreçler, çevre ile ilgili duyumsamalar ve heyecanlardan oluşan arzu ve değerleri konu edinmektedir (İnceoğlu ve Aytuğ, 2009). İnsanın bulunduğu mekâna yüklediği anlam ve mekânın insanda hissettirdikleri olumlu değerler bilişsel sürecin oluşmasına olanak sağlayabilecektir.

Bir meydan tasarlanırken, tasarım ilkelerinin ve tasarım elemanlarının özelliklerinin tam olarak kavranması, doğru bir tasarımın ortaya çıkması için gereklidir. Yapılan öneriler ile meydan görsel ve işlevsel daha etkili hale gelebilecektir. Çalışma sonucunda Orhangazi Meydanı'na olumlu değerler yüklendiği görülmektedir. Meydana kullanıcılar tarafından olumlu değerler yüklenmesi kent için önemli bir olgudur. Ancak olumlu etkinin daha da artırılması önerilerin uygulanması ile mümkün olabilecektir. Bu öneriler ile Meydanın görsel kalitesinin sürekli kalması, geliştirilmesi ve korunması hedeflenmiştir. Bu araştırma sonucunda elde edilen bilgiler, gelecekte Bursa Kenti ve meydanları için yapılacak olan çalışmalara katkı sağlayabilecek, aynı zamanda meydan kavramı ile ilgili çalışmalar için altlık ve yol gösterici bir kaynak olabilecektir.

\section{Kaynaklar}

1. Aalborg, C. (1994). Charter of European Cities \& Townstowards Sustainability.

2. Acarlı, B., Kiper, T. (2018). Kent Meydanlarının Geçmiş ve Günümüz Görüntülerinin Görsel Peyzaj Kalitesinin Saptanması: İstanbul İli Taksim Meydanı Örneği. Inonu University Journal of Art and Design, 8(17):15-31. 
3. Aklanoğlu, F., Arslan, M., (2002). Beypazarı Peyzaj Potansiyelinin Saptanması Üzerine Bir Çalışma, Yüksek Lisans Tezi, Ankara Üni. Fen Bilimleri Enstitüsü, Ankara.

4. Alexander, C., Silverstein, M., Ishikawa, S. (1977). A Pattern Language. New York: Oxford University Press.

5. Altay, E., Batman, Z. (2019). Açık ve Yeşil Alanların Çok Ölçütlü Algı Değerlendirmesi Bursa Uludağ Üniversitesi, Ziraat Fakültesi, Peyzaj Mimarlığı Bölümü, 16059, Bursa

6. Altunkasa, M. F., Yücel, M., (1998). Fahrradrouten als Element des Nahverkehrssystems im oberen Stadtentwicklungsgebiet Nord-West Adana. TU International, Nr. 42/43 Dezember, Berlin.

7. Altunkasa, M. F., Yücel, M., Yılmaz, K. T., Atmaca, M., İlter, A. A., Uslu, C., (1999). Çukurova Üniversitesi Kampusunda Fiziksel Planlamada Kullanılacak Verilerin Bilgisayar Yardımıla Belirlenmesi. Ç.Ü. Ziraat Fakültesi Araştırma Projesi (BAP-PM-96/01), Adana (100 S.).

8. Argan, A. (2019). Peyzaj Tasarımında İşitsel Ve Görsel Kurgunun Mekân Algısı Ve Yönetimi Üzerine Etkileri, T.C. Ordu Üniversitesi Fen Bilimleri Enstitüsü Yüksek Lisans Tezi Peyzaj Mimarlığı Anabilim Dalı Ordu 2019

9. Arheim, R., (1977). The dynamics of architectural form, University of California Press, California, p. 69-76

10. Ateş, N. (2020). Türkiye'de Tarihi Dokusu İle Kimlikleşmiş Kent Meydanlarının Değiş̧imleri Üzerine Bir Araştırma. Yüksek Lisans Tezi, Karabük Üniversitesi Mimarlı Anabilim Dalı. Karabük.

11. Aytaş, İ. (2017). Çankırı Kentsel Açık-Yeşil Alan Sisteminin Belirlenmesi, Çankırı Karatekin Üniversitesi Fen Bilimleri Enstitüsü Yüksek Lisans Tezi.

12. Hacıhasanoğlu, O., Aytem N.M. (2005). Mimari Mekânda Renk, Form Ve Doku Değişkenlerinin Algılanması. İstanbul Teknik Üniversitesi Fen Bilimleri Enstitüsü Yüksek Lisans Tezi

13. Baker, G., (1989). Design strategies in architecture: An approach to the analysis of form, E. and F.N. Spon, London, p,34-46.

14. Çağlayan, S. (2014). Sanatta Görsel Algının Literatür Açısından Değerlendirilmesi Eğitim Ve Öğretim Araştırmaları Dergisi Journal Of Research İn Education And Teaching Şubat 2014 Cilt:3 Sayı:1 Makale No: 16 Issn: 2146-9199

15. Çanaçığlu, N. G. (2011). İstanbul'da Farklı Sosyal Grupların Yerleştiği Çevrelerde Yaşayan Çocukların Algisal Süreçlerinin Bölgesel Haritalar Yöntemiyle İrdelenmesi, Yüksek Lisans Tezi, İstanbul Teknik Üniversitesi, Fen Bilimleri Enstitüsü

16. Carmona, M. ve diğerleri, (2003), Public Places, Urban Spaces: The Dimensions of Urban Design, Architectural Press, Oxford.

17. Çınar, Altınçekiç, H.S., Ergin, B., Tanfer, M. (2014). Tarihsel Süreç İçinde Kent Kimliğinin Mekânsal Kalite Değerlendirmesi Üzerine Bir Araştırma (Taksim Meydanı). Artvin Çoruh Üniversitesi Orman Fakültesi Dergisi, 15(2):132-148.

18. Çınar, S . Çetindă̆, K. (2009). Görsel Algılamada Işık ve Renk Faktörü: Sultanahmet Meydanı ve Çevresi Örneği, İ.Ü Orman Fakültesi,Peyzaj Mimarlı̆̆ı, Peyzaj Planlama ve Tasarım ABD, Bahçeköy, İstanbul.

19. Cooper Marcus, C. Ve C. Francis, (1986). People Places: Design Guidelines for Urban Open Space, Van Nostrand Reinhold, New York.

20. Demirel, T., (2008). Kent Meydanları Yer Seçimine Metodolojik Bir Yaklaşım: Adana Kenti Örneği, Çukurova Üniversitesi Bilimleri Enstitüsü Peyzaj Mimarlığı Anabilim Dalı,Yüksek Lisans Tezi, Adana

21. Durak, H. (2018). Tarihi Kent Meydanları Ve Donatılarının Peyzaj Mimarlığı Açısından İrdelenmesi; Sultanahmet Meydanı Örneği Yüksek Lisans Tezi Peyzaj Mimarlığı Anabilim Dalı Isparta

22. Ender, E. (2011). Adana ili Çukurova ilçesi aktif yeşil alanlarının nitelik ve nicelik açısından irdelenmesi. Çukurova Üniversitesi Fen Bilimleri Enstitüsü Peyzaj Mimarlığı Anabilim Dalı. Yüksek Lisans Tezi. Adana.

23. Ender, E., Uslu, C., (2018). Multi-criteria evaluation of active green spaces in Cukurova district in Adana. Mediterranean Agricultural Sciences. 31(1): 27-35.

24. Eren, T.E. (2012). Kentsel Açık Ve Yeşil Alanların Kentsel Tasarım Teorilerine Göre İncelenmesi: Trabzon Kent Merkezi Örneği, Karadeniz Teknik Üniversitesi, Peyzaj Mimarlığı Anabilim Dalı

25. Erdönmez, E., Çelik, F. (2016). Kentsel Mekânda Kamusal Alan İlișkileri Publıc Space Relatıons In The Urban, Yıldız Teknik Üniversitesi Mimarlık Fakültesi Mimarlık Bölümü Yıldız-Beşiktaş / İstanbul.

26. Giritlioglu, C. (1991). Şehirsel Mekân Ögeleri Ve Tasarımı 1. İtü Kütüphanesi Sayl:1459. İtü Mimarlık Fakültesi Baskı Atölyesi, İstanbul.

27. Glazer, N., Lilla, M., (1987). The Public Face of Architecture: Civic Culture and Public Spaces. New York: Free Press, 1987.

28. Gold, S. M., (1980). Recreation Planning and Design.McGraw-Hill, New York.

29. Gültekin, B., (2007). Kent İçi Yolların, Yaya Kullanımına Yönelik Değerlendirilmesinde Çözümlemeli Bir Yaklaşım: Adana Örneği. Çukurova Üniversitesi, Peyzaj Mimarlığı Anabilim Dalı, Yüksek Lisans Tezi, Adana. 
30. Günal, B. (2006). İnsan-Mekân İletişim Modeli Bağlamında Konutta Psiko-Sosyal Kalitenin İrdelenmesi, Doktora Tezi, İstanbul Teknik Üniversitesi Fen Bilimleri Enstitüsü.

31. Gündoğdu, H.M., Ŭ̆uz, M.B. (2020). İnsan-Mekân Etkileşimi Bağlamında Kırklareli Merkez Yayla ve Vilayet Meydanları Kullanılabilirlik Durumunun Araştırılması. Kent Kültürü ve Yönetimi Hakemli Elektronik Dergisi, 13(2):315-337.

32. Hançer, G. (2019). Toplu Konut Alanlarında Kentsel Mekân Kalitesinin Değerlendirilmesi; Gaziantep Örneği, Yüksek Lisans Tezi, T.C. Hasan Kalyoncu Üniversitesi Fen Bilimler Enstitüsü.

33. İnceoğlu, M., Aytuğ, A. (2009). Kentsel Mekânda Kalite Kavramı. Megaron. 4(3):131-146.

34. Kalkan, N., (2013). Malatya kenti aktif yeşil alanlarının nitelik ve nicelik açısından irdelenmesi. Çukurova Üniversitesi Fen Bilimleri Enstitüsü Peyzaj Mimarlığı Anabilim Dalı. Yüksek Lisans Tezi. Adana

35. Karakaş, O. (2019). Kentsel Mekân Olarak Meydanların Mekânsal Kalitesinin Ölçülmesine Yönelik Bir Araştırma: Malatya Yeni Cami Meydanı. Yüksek Lisans Tezi, Uü Fen Bilimleri Enstitüsü, Mimarlık Anabilim Dalı. Elazı̆̆.

36. Konaklı, N., Altunkasa, M.F., Uslu, C., Sirel, B., (2010). Mekansal Algılama ve Mekanın Davranışsal Başarımı: Adana 5 Ocak ve Uğur Mumcu Meydanları Örneği. Peyzaj Mimarlığı IV.Kongresi Bildiriler Kitabı. İzmir.

37. Krier, R., (1979), Urban Space, New York, Rizzoli.

38. Kuloğlu, N. (2013). Boşluğun Devinimi: Mimari Mekandan Kentsel Mekana. International Journal of Architecture and Planning Volume 1, Issue 2, pp:201-214.

39. Küçükerbaş. E., B. Özkan. (1994). Bir Meydan Tasarım Sürecinin Germencik Örneğinde Ortaya Konulması. E.Ü. Ziraat Fakültesi Peyzaj Mimarlığı Bölümü Bilim Ofset, Bornova. İzmir

40. Lang, J., (1987). Creating architectural theory: The role of the behavioral sciences in environmental design, Van, Nostrad Reinhold, New York, pp. 78-89.

41. Lang, J. (2005), Urban Design: A Typology of Procedures and Products, Architectural Press, Oxford.

42. Lynch, K., (1973). What Time Is This Place? The Massachusetts institute of technology, ISBN 0-262-620324 , MIT, pp.56-67.

43. Madanipour, A. (1996), Design of Urban Space, Wiley, New York.

44. Nasar J.L., (1994). Urban design aesthetics: The evaluative qualities of building exteriors, Environment and Behavior, 26, 3, 377-401

45. Özer, M. N., Ayten, M. (2005). Tarihsel Süreç İçerisinde Meydanlar Ve Gelişimi, Gazi Üniversitesi Fen Bilimleri Enstitüsü, Basılmamış Yüksek Lisans Kentsel Doku Değerlendirme Dersi Ödevi, Ankara.

46. Özer. E. (2019). Burdur Cumhuriyet Meydanının Kentsel Bir Mekân Olarak İrdelenmesi T.C. Burdur Mehmet Akif Ersoy Üniversitesi Fen Bilimleri Enstitüsü Mekânsal Planlama Ve Tasarım Anabilim Dalı Yüksek Lisans Tezi

47. Oktay, D. (2007). Kentsel Kimlik Ve Canlılık Bağlamında Meydanlar: Kuzey Kıbrıs’ta Bir Meydana Bakış, Doğu Akdeniz Üniversitesi, Mimarlık Bölümü

48. Pouya, S., Sekman, B. (2020). Kullanım Sürecinde Değerlendirilmesi Malatya Kent Meydanları Örneği. Adnan Menderes Üniversitesi Ziraat Fakültesi Dergisi, 17(2):189-197.

49. Relph, E. (1976). Place and Placelessness. Pion, London

50. Ringas, D., Christopoulou, E., Stefanidakis, M. (2011). "Urban Memory İn Space And Time”, Styliaras, G., Koukopoulos D., Lazarinis, F. (Eds.) Handbook Of Research On Technologies And Cultural Heritage. Information Science Reference, New York.

51. Semerci, F. (2008). Kentsel Tasarım Gereklilikleri Açısından Beyazıt Meydanı Örneği, Yüksek Lisans Tezi. Yıldız Teknik Üniversitesi Fen Bilimleri Enstitüsü, İstanbul, Türkiye.

52. Şahin, S. (2015). Kentte Meydanın Rolü: Ankara -Kızılay Meydanı, T.C. Atılım Üniversitesi Sosyal Bilimler Enstitüsü İç Mimarlık Ve Çevre Tasarımı Anabilim Dalı Yüksek Lisans Tezi

53. Tanrıbir, E., Akten, M. (2020). Isparta Kent Merkezinin Mekânsal Algı Değerlendirmesi. Mimarlık Bilimleri Ve Uygulamaları Dergisi, 5(2):165-180.

54. Taş̧̧ı, H. (2012). Kent Meydanı İle Kent Kimliği İlişkisi Üsküdar Meydanı Örneği Doktora Tezi T.C. Marmara Üniversitesi Sosyal Bilimler Enstitüsü Kamu Yönetimi Anabilim Dalı Mahalli İdareler Ve Yerinden Yönetim Bilim Dalı, İstanbul.

55. Tırnakçı, A. (2020). Kentsel Peyzaj Tasarımı Açısından Tarihi Kayseri Kent Meydanının (Cumhuriyet Meydanının) İrdelenmesi. Turkish Journal of Forest Science, 4(2), 314-332.

56. Torlak, G. M., Yerli, Ö. (2019). Mersin Kent Meydanlarının Peyzaj Mimarlığı Açısından Değerlendirilmesi The Evaluation of Mersin City Squares In Terms of Landscape Architecture Journal of Forestry vol.15, issue.1, p.24-37 Category: Research Article Journal of Forestry http://dergipark.gov.tr/journal/256/workflow/active ISSN 2148-7855 (online), ISSN 2148-7871 Duzce University Forestry Faculty

57. Trancik, R.,(1986). Finding lost space, theories of urban space , p.256, New york. 
58. Url 1 (2021).http://www.mimarlikdergisi.com/index.cfm?sayfa=mimarlik\&DergiSayi=52\&RecID=1288 (Erişim Tarihi 24.11.2021)

59. Url 2 (2013). Bursa'da Zaman Dergisi - Orhangazi Meydanı (Bursadazamandergisi.Com)_[Erişim Tarihi 02.12.2020].

60. Uskan Demir, M., Akkurt, E., Erdönmez, E.M. (2021). Beşiktaş'ta Bulunan Kamusal Alanların Mekansal Kalite Bağlamında Değerlendirilmesi. Journal of Environmental and Natural Studies, 2(3):154-173

61. Uslu, C., Altunkasa, M. F., Yılmaz, E., Boyacıgil, O., (2004). Adana Kuzeydoğu Kentsel Gelişme Alanında Bisikletli Bağlantı Olanaklarının Araştırılması. Ç.Ü.Ziraat Fakültesi Dergisi Cilt 19, sayı 3, Adana.

62. Ünal, M., (2014). Aktif yeşil alanların rekreasyonel hizmet etkinliğinin saptanması: Çukurova ilçesi örneği. Çukurova Üniversitesi Fen Bilimleri Enstitüsü Peyzaj Mimarlığı Anabilim Dalı. Yüksek Lisans Tezi. Adana.

63. Uzgören, G.. Erdönmez E. (2017). Kamusal Açık Alanlarda Mekan Kalitesi Ve Kentsel Mekan Aktiviteleri İlişkisi Üzerine Karşılaştırmalı Bir İnceleme A Comparative Study On The Relationship Between The Quality Of Space And Urban Activities In The Public Open Spaces

64. Vural, H. (2012). Tarım ve Gıda Ekonomisi İstatistiği. Bursa: Uludağ Üniversitesi Ziraat Fakültesi Ders Notlar1 No: 107.

65. Whyte, W. H. (1989), City: Rediscovering Its Center, Doubleday, New York

66. Zucker, P., (I959). Town And Square. Columbia 'University Press, New York. 